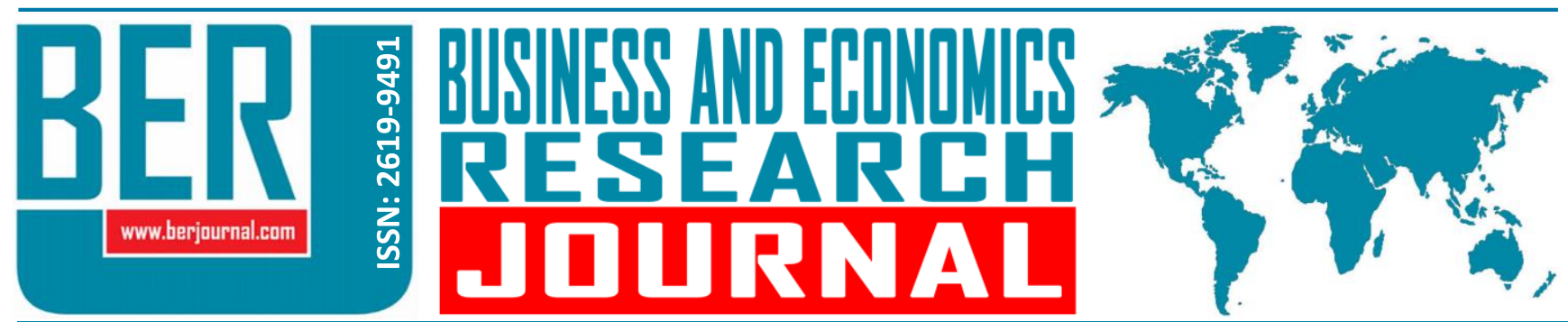

Business and Economics Research Journal Vol. 11, No. 3, 2020, pp. 875-889 doi: 10.20409/berj.2020.287

\title{
Örgütsel Etik İklim ve Çalışan Sesliliği Davranışı Arasındaki İlişki: Psikolojik Güvenliğin Aracı Rolü ${ }^{1}$
}

\author{
Mesut Soyalin ${ }^{\mathrm{a}}$, Canan Nur Karabey ${ }^{\mathrm{b}}$
}

Öz: Bu çalışmanın amacı örgütsel etik iklim, çalışan sesliliği ve psikolojik güvenlik arasındaki ilişkileri ele almaktır. Çalışmada örgütsel etik iklimin psikolojik güvenlik aracılığıyla çalışan sesliliği üzerindeki etkisi incelenmiştir. Çalışmanın teorik kısmında sırasıyla örgütsel etik iklim, çalışan sesliliği ve psikolojik güvenlik kavramları açıklanmıştır. Hipotezlerin testi için Siirt ilinde görev yapan 409 sağlık çalışanından anket tekniği aracılığıyla veri toplanmıştır. Veriler SPSS programıla analize tabi tutulmuş ve faktör, korelasyon ve regresyon analizleri gerçekleştirilmiştir. Gerçekleştirilen analizlerde çalışan sesliliği değişkeni, teşvik edici ve yasaklayıcı seslilik olmak üzere iki boyutta ele alınmıştır. Araştırma bulgularına göre örgütsel etik iklimin, çalışan sesliliği davranışını ve çalışanların psikolojik güvenlik algısını olumlu yönde etkilediği görülmüştür. Ayrıca analizler sonucunda örgütsel etik iklimin çalışan sesliliği üzerindeki etkisinde psikolojik güvenlik değişkeninin kısmi aracılık rolü üstlendiği bulgusuna ulaşılmıştır.

\section{The Relationship between Organizational Ethical Climate and Employee Voice Behaviour: The Mediating Role of Psychological Safety}

Abstract: The aim of this study is to investigate the relationships among organizational ethical climate, psychological safety and employee voice behaviour. The effect of perceived organizational ethical climate on employee voice behaviour through psychological safety was investigated. In the theoretical framework, the concepts of organizational ethical climate, psychological safety and employee voice behaviour were explained respectively. To test the hypotheses, data were gathered through a survey conducted on 409 employees working at health sector in Siirt province. Data were analyzed by using SPSS and factor, correlation and regression analyzes were performed. In the analyzes performed, the employee voice was addressed in two dimensions: promotive and prohibitive voice. According to the findings of the research, organizational ethical climate positively affects employee voice behaviour and psychological safety. Moreover, it was observed that the effect of perceived organizational ethical climate on employee voice is partially mediated by psychological safety.

Anahtar Sözcükler: Örgütsel Etik İklim, Çalışan Sesliliği Davranışı, Psikolojik Güvenlik, Yasaklayıcı Seslilik, Teşvik Edici Seslilik

JEL: M10, M12, M14

$\begin{array}{ll}\text { Geliş } & : 24 \text { Mart } 2020 \\ \text { Düzeltme } & : 13 \text { Mayıs 2020 } \\ \text { Kabul } & : \text { 18 Haziran 2020 } \\ \text { Tür } & : \text { Araştırma }\end{array}$

Keywords: Organizational Ethical Climate, Employee Voice Behaviour, Psychological Safety, Promotive Voice, Prohibitive Voice

JEL: M10, M12, M14

$\begin{array}{ll}\text { Received } & : 24 \text { March } 2020 \\ \text { Revised } & : \text { 13 May } 2020 \\ \text { Accepted } & : \text { 18 June } 2020 \\ \text { Type } & : \text { Research }\end{array}$

a Asst. Prof., PhD., Siirt University, Faculty of Economics and Administrative Sciences, Department of Social Work, Siirt, Turkiye, msoyalin@hotmail.com (ORCID ID: 0000-0003-1475-0905)

b Assoc. Prof., PhD., Atatürk University Faculty of Economics and Administrative Sciences, Department of Business Administration, Erzurum, Turkiye, ckarabey@atauni.edu.tr (ORCID ID: 0000-0003-0597-3605) 


\section{Giriş}

Bu çalışmada örgütsel etik iklim, çalışan sesliliği ve psikolojik güvenlik olguları incelenmektedir. Artık örgütler sadece ürettikleri mallar veya sundukları hizmetler açısından değil aynı zamanda sahip oldukları sosyal sorumluluk bilinci ve etik değerler açısından da tanımlanmaktadır. Rekabet ortamında ayakta kalmak isteyen örgütler bunu başarabilmek için; toplum, çalışanlar, tedarikçiler ve tüketiciler gibi çeşitli paydaş gruplarına yönelik bir takım sorumlulukları yerine getirmek mecburiyetindedir. Bu noktada örgüt içerisinde etik bir iklimin yaratılması ve etik davranışlara yönelik değerlerin saptanması, örgütsel karar ve uygulamalara yön verebilecektir. Diğer taraftan çalışanların öneri ve fikirlerini örgüt içerisinde serbestçe paylaşmaları örgütün mevcut durumunu geliştirerek rekabet üstünlüğü elde etmesi açısından hayati bir öneme sahiptir.

Örgüt ya da birim performansını geliştirmeyi amaçlayan iş ile ilgili konular hakkında fikirler, öneriler, endişeler veya görüşlerin isteğe bağlı biçimde iletilmesi olarak tanımlanan (Morrison, 2011) çalışan sesliliği, örgütsel performansı geliştirmek, değişim süreçlerini başlatmak ve takım öğrenmesini kolaylaştırmak gibi bir çok olumlu sonuç doğurabilmektedir. Örgütsel süreçler açısından önem taşıyan diğer bir değişken ise psikolojik güvenliktir. Kendilerini psikolojik olarak güvende hisseden çalışanlar fikir, öneri ve isteklerini ayıplanma veya tepki görme korkusu olmadan paylaşabilmektedir. Bu bağlamda örgütlerin hayatta kalması ve gelişmesine olanak sağlayabilen yaratıcı ve yenilikçi iş fikirlerinin ortaya çıkarılması psikolojik güvenlik ortamının sağlanmasına bağlı olup olmadığının ortaya çıkarılması önem arz etmektedir.

Bu araştırmada, örgütsel etik iklim algısı ile çalışan sesliliği davranışı arasında bir ilişki olup olmadığı ve psikolojik güvenliğin bu ilişkide aracı bir rol oynayıp oynamadığı incelenmektedir.

\section{Kavramsal Çerçeve}

\section{1. Örgütsel Etik İlim Kavramı}

Etik iklim örgütün politika, uygulama ve prosedürlerine yansımış olan ve örgüt tarafından desteklenen, ödüllendirilen ve arzu edilen etik davranışlara yönelik ortak bakış açısını yansıtan bir kavramdır (Guerci vd., 2013). Bu doğrultuda etik bir seçim yapması gereken bir çalışan, örgütteki ahlâki yükümlülüklere ilişkin algıladığı yasakları, izinleri ve yönergeleri yorumlayarak "ben ne yapmalıyım?" sorusuna cevap aramaktadır (Victor ve Cullen, 1988). Bu yönüyle etik iklim, çalışan davranışlarını etik bağlamda inceleyen ve düzenlemeler getiren bir kavram olarak ele alınmaktadır. Üst yönetimin etik problemlere ilişkin getirdiği bu düzenlemeler, etik bir ikilemle karşılaşan çalışanlara ne yapmaları gerektiği konusunda rehberlik etmektedir.

Victor ve Cullen (1988) örgütsel etik iklimi, çalışanların etik bağlamda örgütsel uygulamalar ve prosedürler hakkındaki görüşleri olarak tanımlamakta ve bir örgütteki etik iklimin yönetimin tutum ve davranışlarını yansıttığını ileri sürmektedir. Dolayısıyla bir örgütün yönetiminde etik konularda hakim olan görüş, örgüt üyelerinin sergileyecekleri tutum ve davranışlara yön vermektedir.

Trevino vd. (1998) örgütün etik davranışa destek vermesi durumunda, çalışanların daha fazla etik davranış sergileyeceklerini ve örgütlerine daha fazla bağıııı duyacaklarını ortaya koymuştur. Diğer taraftan bir örgütün yöneticilerinin etik iklime ilişkin bilgiye sahip olması, çalışanlar arasında etik davranışı teşvik eden politika ve uygulamaların oluşturulmasını mümkün kılabilecektir. Ayrıca çalışanların etik konuların önemini algılamaları yönetimin etik önceliğe sahip olmasına bağlıdır. Çalışanlarının üst yönetimin etik değerlere fazla önem vermediğini düşündüğü örgütlerde etik olmayan bir iklimin ortaya çıkması muhtemeldir (Shafer, 2015). Sonuç olarak örgüt yönetiminin etik konulara yönelik eğilimleri çalışanların etik algılarını da yönlendirmektedir. Eğer örgüt içinde yönetim tarafından etik problemler üzerinde yeterince durulmuyorsa ya da bunlar önemsenmiyorsa, çalışanlar da bu tür problemlere kayıtsız kalacaktır.

\section{2. Çalışan Sesliliği Davranışı}

Çalışan sesliliği bir örgütün veya birimin işlevlerini iyileştirmek amacıyla çalışanlar tarafından işle ilgili konular hakkında fikir, öneri, endişe ve düşüncelerin gönüllü bir biçimde yukarı yönlü olarak iletilmesidir (Morrison, 2011). Çalışanın iş yerindeki problemlerini açıkça iletebilme davranışı olarak da tanımlanan çalışan sesliliği, bazı durumlarda mevcut durumdan duyulan rahatsızlıktan kaynaklanmakta ve çalışanlar tarafından 
iş şartlarının iyileştirilmesi için bir fırsat olarak görülmektedir (Kassing, 2002). Başka bir ifadeyle seslilik yalnızca işle ilgili konularda eleştiri yapmayı değil, aynı zamanda örgütsel faaliyetleri iyileştirmeye yönelik yapıcı meydan okumayı teşvik eden ve değişim için proaktif olarak önerilerde bulunmayı amaçlayan davranışlar olarak da tanımlanmaktadır (Van Dyne vd., 2003). Bu anlamda seslilik davranışlarının hem verimlilik artışının hem de iş tatmininin sağlanması konusunda önemli bir rol oynayacağı söylenebilir.

Çalışan sesliliği farklı şekillerde kavramlaştırılabilmektedir; ancak seslilik davranışına ilişkin bakış açılarının altında yatan en temel düşünce, çalışanların doğrudan ya da dolaylı olarak karar verme süreçlerine katılma ve katkı sağlama hakkının olduğu düşüncesidir (Hodson, 2001). Yönetim ve çalışanlar arasındaki iki yönlü diyaloğun kolaylaştırıması ile ortaya çıkan çalışan sesliliği aynı zamanda çalışanlara örgütsel kararları ve yönetim politikalarını etkileme potansiyeli taşıyan fikir ve endişelerini açıkça ifade etmeleri için bir fırsat sağlamaktadır (Holland vd., 2013). Kısaca seslilik davranışı, çalışanların işyeri fonksiyonlarının iyileştirilmesine yönelik sahip oldukları yapıcı düşünce ve fikirlerini gönüllü olarak paylaşmalarını ifade etmektedir. Seslilik davranışlarının sergilenmediği durumlarda çalışanlar mümkün olduğu ölçüde sahip oldukları bilgileri saklamayı tercih ederek sessiz kalacak ve önemli bilgileri paylaşma konusunda istekli olmayacaktır.

Maynes ve Podsakoff (2013) çalışan sesliliğini teşvik edici veya yasaklayıcı seslilik olmak üzere iki boyutta incelemiştir. Bu araştırmacılar, çalışanların örgüt için zararlı olabilecek davranışlar, faaliyetler veya uygulamalara yönelik endişelerini dile getirmesini yasaklayıcı seslilik olarak tanımlarken çalışanların örgüt veya grup fonksiyonlarını iyileştirmek amacıyla ileri sürdükleri öneri ya da fikirleri ise teşvik edici seslilik olarak tanımlamıştır.

\subsection{Psikolojik Güvenlik Kavramı}

Psikolojik güvenlik çalışanların konuştukları için utandırılmayacakları, reddedilmeyecekleri ve cezalandırılmayacakları konusunda sahip oldukları güven duygusu olarak tanımlanmaktadır (Edmondson, 1999). Edmondson (1999) psikolojik güven lik kavramını çalışanların kişiler arası risk alabileceklerine dair ortak inançları şeklinde ifade etmiştir. Bahsi geçen riskler arasında geri bildirimde bulunmak, soru sormak, hata bildirmek veya yeni bir fikir önermek gibi davranışlar sayılabilir. Kahn (1990) ise psikolojik güvenliğin örgütteki destekleyici yönetimi, rol açıklığını ve kendini ifade etme özgürlüğünü yansıttığını ileri sürmüştür. Yani örgütte kendilerini psikolojik olarak güvende hisseden çalışanlar yöneticilerinden destek görmekte ve fikir yada önerilerini çekinmeden kolaylıkla ifade edebilmektedir.

Psikolojik güvenlik öğrenme davranışları, bilgi paylaşımı, vatandaşlık davranışları ve yaratıcılık yoluyla işe adanmayı güçlendirmektedir. Ayrıca performans, öğrenme, katılım, bilgi paylaşımı, tatmin ve bağlıık gibi örgütsel sonuçları olumlu yönde etkilemektedir (Frazier vd., 2017). Diğer taraftan bireylerin kendilerini psikolojik olarak güvende hissetmedikleri, tahmin edilemeyen ve tehdit edici iş koşullarının olduğu örgütlerde çalışanlar risk almaktan çekindikleri için işten ayrılma düşüncesinde olabilmektedir.

\section{Literatür ve Araştırmanın Hipotezleri}

Örgütsel etik iklim, çalışan sesliliği ve psikolojik güvenlik kavramlarının birbirleriyle olan etkileşimini ortaya koymak için kavramları birlikte ele alan çalışmalar literatür taraması aracılığıyla incelenmiştir. Bu çalışmalarda örgütsel etik iklimin çalışan sesliliğini olumlu yönde etkilediği bulunmuştur (Chen ve Hou, 2015; Meydan vd., 2016; Paşa ve ışık, 2017; Lee vd., 2017). Ayrıca bu çalışmalarda psikolojik güvenliğin çalışanların seslilik düzeylerini artırdığı ortaya konulmuştur (Detert ve Burris, 2007). Bahsi geçen çalışmalardan yola çıkılarak araştırma modeli kurgulanmış ve bu model doğrultusunda hipotezler oluşturulmuştur.

\section{1. Örgütsel Etik İklim İle Çalışan Sesliliği Arasındaki ilişki}

Çalışan sesliliğini etkileyen birçok faktör bulunmaktadır. Bu faktörler arasında örgütün yönetim ve çalışma biçimini yansıtan örgüt iklimi öne çıkmaktadır. Etik değerlere önem veren ve çalışanlarını bu değerlerle uyum içerisinde olmaları konusunda teşvik eden iklime sahip bir örgütte çalışan kişilerin seslilik davranışı sergilemeleri beklenmektedir. Yapılan birçok çalışma bu durumu doğrular niteliktedir. Brown vd. (2005) etik değerlere sahip olan yöneticilerin, çalışanların fikirlerini dile getirmelerine ve alınacak kararlara 
katılmalarına imkân tanıdığını öne sürmektedir. Benzer şekilde Walumbwa ve Schavbreck (2009) de, yüksek ahlâk standartlarını çalışanlarına aktaran etik bir liderin, takipçilerini sahip oldukları fikir ve önerileri seslendirmeleri konusunda teşvik ettiğini öne sürmektedir. Bu bağlamda etik değerlere sahip yöneticilerin yer aldığı bir örgüt iklimi, çalışanları hem etik konularda hem de işle ilgili diğer konularda görüş ve deneyimlerini seslendirmeleri hususunda cesaretlendirebilir. Örgütün sahip olduğu etik değerlerin çalışan sesliliğini artırması beklenmektedir. Brown ve Trevino (2006) çalışanların örgütlerini etik bir ortam olarak algılamasının ve yöneticilerin etik davranışlar sergilemesinin seslilik davranışlarını artırdığını öne sürmektedir. Chen ve Hou (2015) da etik değerlere bağlı bir örgüt iklimiyle çalışanların sergiledikleri seslilik davranışları arasında doğru yönlü bir ilişkinin var olduğunu öne sürmüştür. Benzer şekilde Lee vd. (2017) Güney Kore'de 154 beyaz yakalı çalışan üzerinde yapmış oldukları çalışma da, etik standartların açıkça tanımlandığı ve etik davranışların desteklendiği bir iklim oluşturmanın, çalışanların etik konularla ilgili fikir ve önerileri dile getirmelerine imkân sağladığını göstermiştir. Dolayısıyla etik örgüt iklimi, çalışanların mevcut iş koşullarını iyileştirmek amacıyla seslilik davranışı sergilemelerini kolaylaştırabilmektedir.

Paşa ve Işık (2017) tarafından yapılan bir çalışmada, okul yöneticileri tarafından sergilenen etik davranışların, kurumdaki çalışanların sessizlik düzeylerini azalttığı görülmüştür. Bu çalışmaya göre etik değerlere önem veren yöneticilerin bulundu örgütlerde, çalışanların seslilik davranışı sergileme intimali artmaktadır. Ayrıca Meydan vd. (2016) tarafından bir eğitim kurumundaki çalışanlar üzerinde yapılan araştırmada çalışanların etik ikilemde kalmaları durumunda alacakları kararlara yol gösterici etik ilkelerin var olması halinde fikirlerini söyleme konusunda daha istekli davrandıkları belirlenmiştir.

Etik iklim çalışanları hangi davranışların etik hangi davranışların ise etik dışı olduğu konusunda yönlendirmektedir. Bu yönlendirmeler; bazen kanun ve yönetmeliklerle bazen de etik kodlar ve kurallar aracılığıyla gerçekleşmektedir. Bu doğrultuda etik dışı bir durum ya da davranışı önceden öngören bir çalışanın sessiz kalmayarak bunu yönetici veya üstlerine aktarması örgüte önemli faydalar sağlayacaktır.

Yukarıdaki görüşlerden hareketle aşağıdaki hipotezler geliştirilmiştir.

$\mathbf{H}_{1}$ : Çalışanların örgütsel etik iklim algısı güçlendikçe teşvik edici seslilik davranışları artar.

$\mathbf{H}_{2}$ : Çalışanların örgütsel etik iklim algısı güçlendikçe yasaklayıcı seslilik davranışları artar.

\subsection{Psikolojik Güvenlik ve Çalışan Sesliliği Arasındaki ílişki}

Davranışsal olarak psikolojik güvenlik kişiler arası ilişkilerde risk alma, seslilik ve açık iletişim konularında ortaya çıkmaktadır (Baer ve Frese, 2003). Örgütte kendilerini psikolojik olarak güvende hisseden çalışanlar yaptıkları hataları kabul etme ve tartışma, kişisel fikirlerini ve bakış açılarını rahatça açıklama ve çalışma arkadaşları tarafından sunulan alternatif görüşlere saygı duyma eğiliminde olacaktır (Matthew, 2011). Güvenlik duygusu yoksa çalışanlar sahip oldukları fikir ve önerileri dışlanacakları ya da cezalandırılacakları korkusuyla dile getirmekten kaçınabilirler.

Yapılan birçok çalışma bireylerin bir davranışı gerçekleştirmeden davranışın getireceği potansiyel fayda ve maliyetleri karşılaştırdıklarını göstermektedir (Morrison ve Rothman, 2009). Çalışanlar sergileyecekleri davranışın getireceği maliyet sağlayacağı faydadan büyük olduğunda davranışı sergilemekten vazgeçebilmektedir (Morrison, 2011). Bu noktada çalışanlar seslilik davranışları sergilediklerinde başkaları tarafından eleştirici ya da ifşacı olarak görülebilmektedir (Armitage ve Conner, 2001). Psikolojik güvenliğin bahsedilen fayda-maliyet tahminini etkilemesi beklenir. Çalışanlar güvensizlik ve korku hissettiklerinde sahip oldukları fikir ve endişeleri ifade etmekten kaçınabilirler. Çalışanlar kendilerini daha güvende hissettiklerinde ise seslilik davranışı gösterme konusunda motive olabilirler.

Seslilik davranışı çalışanlar tarafından çeşitli riskleri barındıran davranışlar olarak görülebilmektedir. $\mathrm{Bu}$ anlamda çalışanlar seslilik davranışı sergilemeye karar verirken birtakım kişilerarası riskleri dikkate almaktadır. Örneğin çalışanlar seslilik davranışının yanlış anlaşıımalara neden olabileceği ya da çalışma arkadaşları ve yöneticileri tarafından cezalandırılacağını ve ilişkilerinin bozulacağı konusunda endişe duyabilirler (Dutton vd., 1997). Psikolojik güvenlik tanımlanan bu tür risklerin değerlendirilmesinde önemli bir rol oynamaktadır (Detert ve Burris, 2007). Çalışanlar yüksek seviyede psikolojik güvenlik algıladıklarında 
seslilik davranışıyla ilişkili olumsuz risk değerlendirmeleri azalacaktır. Bu nedenle psikolojik güvenlik seslilik davranışlarının meydana gelmesi için gerekli ön koşullardan birisi olarak kabul edilebilir.

Yukarıdaki görüşlerden hareketle aşağıdaki hipotezler geliştirilmiştir

$\mathbf{H}_{3}$ : Çalışanların psikolojik güvenlik algısı, teşvik edici seslilik davranışlarını olumlu yönde etkiler.

$\mathbf{H}_{4}$ : Çalışanların psikolojik güvenlik algısı, yasaklayıcı seslilik davranışlarını olumlu yönde etkiler.

\section{3. Örgütsel Etik İklim ve Psikolojik Güvenlik Arasındaki İlişki}

İnsanlar doğumlarından itibaren çevrelerini anlamak ve tepki vermek için belirsizlikleri azaltmaya ihtiyaç duymaktadır. Bu amaçla bulundukları ortamdaki bilgileri araştırmak, işlemek ve kullanmak için motive olurlar. Çalışanlar da bulundukları örgütü anlamak ve onun beklentilerine uygun şekilde davranmak amacıyla belirsizliklerle mücadele etmektedir. Etik algılanan bir iklime sahip olan örgütün yöneticileri çalışanların davranış normlarını ve rollerini netleştirerek ve ahlâki standartlar getirerek örgütte belirsizliği azaltmaya çalışmaktadır (Mayer vd., 2012). Kahn (1990) rol netliğinin belirsizliği azalttığını ve psikolojik güvenliğe olanak sağladığını ifade etmiştir. Bunun yanında etik bir iklime sahip örgütler çalışanların kişiler arası güvenlerini ve saygılarını geliştirerek psikolojik güvenlik ikliminin oluşmasına katkı sunmaktadır (Newman vd., 2014).

Yukarıdaki görüşlerden hareketle aşağıdaki hipotez geliştirilmiştir:

$\mathbf{H}_{5}$ : Çalışanların örgütsel etik iklim algısı güçlendikçe psikolojik güvenlik düzeyleri artar.

\section{Aracı Rolü}

3.4. Psikolojik Güvenlik Algısının Örgütsel Etik Iklim ve Çalışan Sesliliği Davranışı Arasındaki iliş̧ide

Walumbwa ve Schaubroeck (2009) yapmış oldukları bir çalışmada psikolojik güvenlik algısının, etik liderlik ve çalışan sesliliği davranışları arasındaki olumlu yönlü ilişkide aracı bir etkiye sahip olduğunu ileri sürmüştür. Başka bir ifadeyle etik liderlik olgusu çalışanların seslilik davranışlarını psikolojik güvenlik algısı aracılığıyla etkilemektedir.

Literatür incelendiğinde psikolojik güvenlik algısının, örgütsel etik iklim ve çalışan sesliliği davranışı arasındaki ilişkide aracı bir rolü olduğuna dair bir çalışmaya araştırmacı tarafından ulaşılamamıştır. Ancak etik liderlik ile seslilik arasındaki ilişkide psikolojik güvenliğin oynadığı aracı role ilişkin bulgular etik iklim ile seslilik arasındaki ilişkiye yansıtılabilir. Yukarıda öne sürülen hipotezlerde etik iklimin çalışan sesliliğini pozitif yönde etkilediği ve psikolojik güvenlik algısının da çalışan sesliliği ile olumlu bir yönde ilişkiye sahip olduğu ortaya konulmuştur. Buradan hareketle psikolojik güvenlik algısının denkleme dâhil edilmesiyle örgütsel etik iklimin çalışan sesliliği üzerindeki etkisinin azalabileceği, yani psikolojik güvenlik algısının, etik iklim ve çalışan sesliliği davranışı arasındaki ilişkide aracı role sahip olduğu öne sürülebilir.

Yukarıdaki görüşlerden hareketle aşağıdaki hipotezler geliştirilmiştir:

$\mathbf{H}_{6}$ : Çalışanların örgütsel etik iklim algısının teşvik edici seslilik düzeyleri üzerindeki etkisinde psikolojik güvenlik aracı bir rol oynar.

$\mathbf{H}_{7}$ : Çalışanların örgütsel etik iklim algısının yasaklayıcı seslilik düzeyleri üzerindeki etkisinde psikolojik güvenlik aracı bir rol oynar.

\section{Araştırmanın Modeli}

Bu araştırmada, örgütsel etik iklim algısı ile çalışan sesliliği davranışı arasında bir ilişki olup olmadığı ve psikolojik güvenliğin bu ilişkide aracı bir rol oynayıp oynamadığı incelenmektedir. Oluşturulan araştırma modeli Şekil 1'de gösterilmiştir: 
Şekil 1. Araştırmanın Modeli

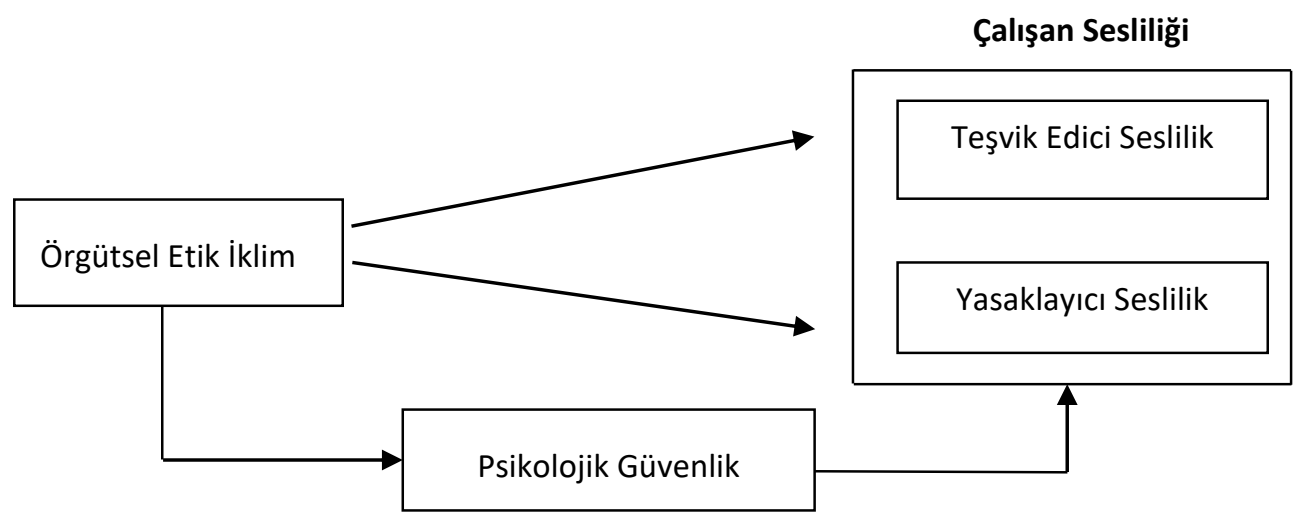

\section{Araştırmanın Örneklemi, Veri Toplama Yöntemi ve Ölçüm Aracı}

Araştırmanın ana kütlesini Siirt ilinde faaliyet gösteren sağlık kurumlarında çalışan kişiler oluşturmaktadır. Kamu kurumlarının vermiş olduğu sağlık hizmetine olan talebin her geçen gün artması sağlık çalışanlarının daha fazla etik ikilem ve problemle karşılaşmasına neden olabilmektedir. Ayrıca Türkiye'de sağlık sektörünün hızla gelişen alanlardan biri olması, sağladığı istihdam sayısının sürekli artış göstermesi ve araştırma değişkenlerinin bu sektördeki çalışanların algı ve davranışlarını değerlendirebilmek için uygun olması gibi nedenler araştırmanın örneklemini bu alandan seçmeye yöneltmiştir. Siirt il Sağlık Müdürlüğü verilerine göre Siirt ilinde faaliyet gösteren sağlık kurumlarında 2019 yılı şubat ayı itibariyle 2.780 çalışan bulunmaktadır. Araştırma evreninden \%95 güven düzeyinde \%5'lik bir hata öngörülerek seçilecek örneklem büyüklüğü 338 olarak belirlenmiştir. Ancak katılımcıların cevaplama hataları göz önüne alınarak anket formları 460 adet hazırlanmış ve araştırmacı tarafından katılımcılara dağıtılmıştır. Dağıtılan anketlerden 442 tanesi geri dönmüştür. Geri dönen anketlerden 33'ü eksik cevaplandırıldığı için değerlendirme dışı bırakılmıştır. Sonuçta 409 adet anket değerlendirilmeye alınmıştır. Analizlerde SPSS 21 paket programı kullanılmıştır.

İlgili literatür taranarak ölçüm araçları incelenmiş ve çalışmanın amacına uygun ölçüm araçları belirlenmiş̧ir. Araştırmada kullanılan soru formu 5 bölümden ve toplam 46 ifadeden oluşmaktadır. Illk bölüm çalışanların cinsiyet, medeni durum, yaş, eğitim durumu, pozisyon, sektör ve çalışma süresi gibi demografik özelliklerini belirleyen 7 maddeden oluşmaktadır. Anketin diğer bölümlerinde ise sırasıyla örgütsel etik iklim algısı, çalışan sesliliği, ve psikolojik güvenlik ile ilgili toplamda 34 ifade yer almaktadır. Ölçeklerde yer alan soruların tümü türkçeye çevirilerek hazırlanmıştır. Soru formunu oluşturan ölçeklere ilişkin temel bilgiler aşağıda açıklanmaktadır:

- Örgütsel Etik Iklim Ölçeği: Örgütsel etik iklim algısının ölçümü için Arnaud (2010) tarafından geliştirilen 19 maddelik Etik İklim Ölçeği kullanılmıştır.

- Çalışan Sesliliği Ölçeği: Çalışanların seslilik düzeylerini ölçmek için Liang vd. (2012) tarafından geliştirilen 10 soruluk çalışan sesliliği ölçeği kullanılmıştır.

- Psikolojik Güvenlik Ölçeği: Çalışanların psikolojik güvenlik algılarını ölçmek için Liang vd. (2012) tarafından geliştirilen 5 soruluk psikolojik güvenlik ölçeği kullanılmıştır. 


\section{Bulgular}

\subsection{Katılımcıların Demografik Özellikleri}

Araştırmaya katılan kadın çalışanların erkek çalışanlardan fazla olduğu $(\% 58,7)$ ve katılımcıların çoğunun bekâr $(\% 57,2)$ olduğu belirlenmiştir. Yaşla ilgili değişkene bakıldığında; 25 yaş ve altı aralığındaki çalışanların oranının $(\% 43,3)$ en yüksek, 40 yaşın üstündeki çalışanların oranının $(\% 7,8)$ ise en düşük oran olduğu sonucuna ulaşılmıştır.

Katılımcılar çalıştıkları pozisyon açısından değerlendirildiğinde hemşire olarak görev yapanların sayıca fazla olduğu gözlemlenmektedir (\%33,7). Eğitim düzeyi açısından incelendiğinde çalışanların büyük kısmının lisans mezunu olduğu görülür $(\% 44,5)$. Ayrıca katılımcıların \%74,6'sı kamu sektöründe çalışmaktadır. Çalışma süresine ilişkin değişkene bakıldığında; $1-4$ yıldır çalışanların $(\% 42,8)$ ağırlığı görülmüştür.

\section{2. Örgütsel Etik İklim Ölçeğine İlişkin Güvenilirlik ve Geçerlilik Analizi}

Araştırmada kullanılan örgütsel etik iklim ölçeğinin güvenilirliğinin tespiti için 19 maddeden oluşan ölçeğin içsel tutarlılı̆ı incelenmiştir. Bir bütün olarak örgütsel etik iklim ölçeğinin güvenilirlik katsayısı 0,918 olarak bulunmuştur. Bu oran ölçek güvenirliğinin yüksek olduğunun göstergesidir.

Örgütsel etik iklim ölçeğinin güvenilirlik analizi yapıldıktan sonra ölçek maddelerinin uygun boyutlar altında toplanmasını sağlamak amacıyla varimaks rotasyonlu açıklayıcı faktör analizi yapıımıştır. Faktör analizi sonuçlarına Tablo 1'de yer verilmiştir.

Tablo 1. Örgütsel Etik iklim Ölçeğine iliş̧kin Açıklayıcı Faktör Analizi

\begin{tabular}{|c|c|c|c|c|}
\hline Faktörler & $\begin{array}{c}\text { Faktör Öz Değer } \\
\text { Yükleri }\end{array}$ & $\begin{array}{l}\text { Açıklanan } \\
\text { Varyans }\end{array}$ & $\begin{array}{l}\text { Toplam } \\
\text { Varyans }\end{array}$ & $\begin{array}{l}\text { Cronbach } \\
\text { Alfa }\end{array}$ \\
\hline Empatik ilgi & 3,305 & 17,396 & 17,396 & 0,938 \\
\hline $\begin{array}{l}\text { EMi6- Çalışanlar herhangi bir durumda bir } \\
\text { kişinin zayıflıklarından yararlanılarak menfaat } \\
\text { sağlanması karşısında üzüntü duyarlar. }\end{array}$ & 0,853 & & & \\
\hline $\begin{array}{l}\text { EMi5- Çalışanlar birisine haksız muamele } \\
\text { yapıldığını gördüklerinde genellikle o kişi için } \\
\text { üzülürler. }\end{array}$ & 0,843 & & & \\
\hline $\begin{array}{l}\text { EMi7-Birimimdeki çalışanlar sorunları olan } \\
\text { kişiler için üzülürler. }\end{array}$ & 0,840 & & & \\
\hline $\begin{array}{l}\text { EMi4- Birimimdeki çalışanlar işiyle ilgili zorluk } \\
\text { yaşayan kişilerin duygularını anlar ve bu } \\
\text { duyguları paylaşır. }\end{array}$ & 0,771 & & & \\
\hline Kendine Odaklanmak & 2,674 & 14,075 & 31,471 & 0,934 \\
\hline $\begin{array}{l}\text { KOD9- Birimimdeki çalışanlar zor bir kararla } \\
\text { karşılaştıklarında ilk önce kendi çıkarlarını } \\
\text { düşünürler. }\end{array}$ & 0,930 & & & \\
\hline $\begin{array}{l}\text { KOD8- Birimimdeki çalışanlar çoğunlukla bir iş } \\
\text { kendi çıkarlarına hizmet edecekse o işi } \\
\text { yaparlar. }\end{array}$ & 0,905 & & & \\
\hline $\begin{array}{l}\text { KOD10- Birimimdeki çalışanların öncelikli } \\
\text { kaygıları kendi kişisel çıkarlarıdır. }\end{array}$ & 0,904 & & & \\
\hline Başkalarına Odaklanmak & 2,514 & 13,232 & 44,703 & 0,903 \\
\hline $\begin{array}{l}\text { BOD12- Herhangi bir durumda birimdeki } \\
\text { herkes için en iyi olan şey büyük öneme } \\
\text { sahiptir. }\end{array}$ & 0,849 & & & \\
\hline $\begin{array}{l}\text { BOD13- Bu birimde en fazla önem verilen } \\
\text { konu birimdeki tüm insanların iyiliği ve } \\
\text { çıkarıdır. }\end{array}$ & 0,833 & & & \\
\hline $\begin{array}{l}\text { BOD11- Birimimdeki çalışanlar toplum ve } \\
\text { insanlık için güçlü bir sorumluluk duygusu } \\
\text { taşırlar. }\end{array}$ & 0,802 & & & \\
\hline
\end{tabular}


Örgütsel Etik İklim ve Çalışan Sesliliği Davranışı Arasındaki İlişki: Psikolojik Güvenliğin Aracı Rolü

Tablo 1. Örgütsel Etik İklim Ölçeğine İlişkin Açıklayıcı Faktör Analizi (Devam)

\begin{tabular}{|c|c|c|c|c|}
\hline Ahlâki Farkındalık & 2,510 & 13,121 & 57,915 & 0,882 \\
\hline $\begin{array}{l}\text { AHF1- Birimimdeki çalışanlar ahlâki (etik) } \\
\text { yönden problemli konuların farkındadır. }\end{array}$ & 0,865 & & & \\
\hline $\begin{array}{l}\text { AHF2- Çalıştığım birimdeki kişiler ahlâki (etik) } \\
\text { bir ikilemi kolayca fark edebilir. }\end{array}$ & 0,857 & & & \\
\hline $\begin{array}{l}\text { AHF3- Birimimdeki çalışanlar ahlâki (etik) } \\
\text { problemlere karşı çok duyarlıdır. }\end{array}$ & 0,829 & & & \\
\hline Ahlâki Karakter & 2,441 & 12,845 & 70,759 & 0,881 \\
\hline $\begin{array}{l}\text { AHF18- Birimimdeki çalışanlar bir hata ortaya } \\
\text { çıktığında bu hatanın sorumluluğunu üzerine } \\
\text { almak gerektiğini düşünür. }\end{array}$ & 0,875 & & & \\
\hline $\begin{array}{l}\text { AHF17- Çalışma arkadaşlarım tüm iş } \\
\text { arkadaşlarına, hatta yardımsever olmayan iş } \\
\text { arkadaşlarına dahi yardım etmek gerektiğine } \\
\text { inanır. }\end{array}$ & 0,819 & & & \\
\hline $\begin{array}{l}\text { E19- Bu birimdeki çalışanlar her durumda } \\
\text { yaptıkları işlerin sorumluluğunu üstlenirler. }\end{array}$ & 0,786 & & & \\
\hline Ahlâki Motivasyon Eksikliği & 2,393 & 12,623 & 83,382 & 0,862 \\
\hline $\begin{array}{l}\text { AHM16- Birimimdeki çalışanlar kıt kaynakları } \\
\text { kontrol etmek için ahlâki (etik) değerlerini bir } \\
\text { ölçüde ihlal etmeye (bunlara aykırı } \\
\text { davranmaya) hazırdır. }\end{array}$ & 0,862 & & & \\
\hline $\begin{array}{l}\text { AHM14- Birimimdeki çalışanlar, kurumda } \\
\text { yükselmek için kuralları çiğnemeye isteklidir. }\end{array}$ & 0,849 & & & \\
\hline $\begin{array}{l}\text { AHM15- Bu birimde güç dürüstlükten daha } \\
\text { önemlidir. }\end{array}$ & 0,844 & & & \\
\hline KMO: $0,883 \quad$ Barlett küresellik Testi: 5,942 & $P: 0,000$ & & & \\
\hline
\end{tabular}

Örgütsel etik iklime ilişkin on dokuz maddenin KMO değeri 0,883 olup, küresellik testi de anlamlıdır. Yukarıdaki tabloya göre on dokuz madde, altı ayrı faktöre ayrılmıştır. Elde edilen altı faktör toplam varyansın $\% 83,382$ 'sini açıklamaktadır.

\section{3. Çalışan Sesliliği Ölçeğine İlişkin Güvenilirlik ve Açıklayıcı Faktör Analizi}

Araştırmada çalışanların seslilik düzeyini ölçmek için kullanılan ölçeğin güvenilirliğini tespit etmek amacıyla ölçeğin içsel tutarlılı̆ı incelenmiştir. Çalışan sesliliği ölçeğinin güvenilirlik katsayısı 0,920 olarak bulunmuştur. Bulunan bu oran ölçeğin güvenilirliğinin yeterli olduğunu ifade etmektedir.

Çalışan sesliliği ölçeğinin güvenilirlik analizi yapıldıktan sonra ölçek ifadelerinin uygun boyutlar altında toplanmasını sağlamak amacıyla varimaks rotasyonlu açıklayıcı faktör analizi uygulanmıştır. Ölçekteki 10 maddeye yapılan faktör analizinde maddeler iki faktöre yüklenmiş ve bulgular Tablo 2'de verilmiştir.

Çalışan sesliliğine ilişkin on maddenin KMO değeri 0,922 olup, küresellik testi de anlamlıdır. Yukarıdaki tabloya göre on madde, iki ayrı faktöre ayrılmıştır. Kaynak olarak alınan ölçeğe uygun biçimde bu faktörler adlandırımıştır. Bu doğrultuda beş maddeden oluşan birinci faktöre "teşvik edici seslilik" adı verilmiştir. Bu faktör toplam varyansın \%36,872'sini açıklamaktadır. İkinci faktör yine beş maddeden oluşmakta ve "yasaklayıcı seslilik" olarak adlandııımaktadır. Bu faktör toplam varyansın \%35,248'ini açıklamaktadır. Elde edilen iki faktör toplam varyansın \%72,120'sini açıklamaktadır. 
Tablo 2. Çalışan Sesliliği Ölçeğine İlişkin Açıklayıcı Faktör Analizi

\begin{tabular}{|c|c|c|c|c|}
\hline Faktörler & $\begin{array}{l}\text { Faktör } \\
\text { Yükleri }\end{array}$ & $\begin{array}{l}\text { Açıklanan } \\
\text { Varyans }\end{array}$ & $\begin{array}{l}\text { Toplam } \\
\text { Varyans }\end{array}$ & $\begin{array}{l}\text { Cronbach } \\
\text { Alfa }\end{array}$ \\
\hline Teşvik Edici Seslilik & 3,687 & 36,872 & 36,872 & 0,913 \\
\hline $\begin{array}{l}\text { TES8- İş arkadaşlarımı utandırabilecek olsa bile iş } \\
\text { biriminde verimliliği azaltabilecek bazı olumsuz } \\
\text { davranışları iş arkadaşlarımın anlamasını sağlamaya } \\
\text { çalışırım. }\end{array}$ & 0,861 & & & \\
\hline $\begin{array}{l}\text { TES9- İ̧̧ arkadaşlarımla olan ilişkilerime zarar verse } \\
\text { bile iş birimimde problem ortaya çıtığında iş } \\
\text { arkadaşlarımın bunları görmesini sağlamaya } \\
\text { çalışırım. }\end{array}$ & 0,852 & & & \\
\hline $\begin{array}{l}\text { TES10- İşyerinde koordinasyon (uyumlu çalışma) } \\
\text { sorunları doğduğunda bunların yöneticiler } \\
\text { tarafından fark edilmesini sağlamaya çalışırım. }\end{array}$ & 0,803 & & & \\
\hline $\begin{array}{l}\text { TES7- Görüşlerime zıt (karşıt) görüşler olsa bile, iş } \\
\text { biriminde ciddi bir kayba neden olabilecek } \\
\text { problemler hakkında dürüstçe konuşurum. }\end{array}$ & 0,768 & & & \\
\hline $\begin{array}{l}\text { TES6- İş performansını düşürebilecek olan } \\
\text { istenmeyen davranışlara karşı iş arkadaşlarıma } \\
\text { tavsiyelerde bulunurum. }\end{array}$ & 0,745 & & & \\
\hline Yasaklayıcı Seslilik & 3,525 & 35,248 & 72,120 & 0,885 \\
\hline $\begin{array}{l}\text { YAS2- İş birimime faydalı olabilecek yeni projeler } \\
\text { için fikirler üretirim ve bunları açıklarım. }\end{array}$ & 0,834 & & & \\
\hline $\begin{array}{l}\text { YAS3- İş birimimin çalışma anlayışını ve } \\
\text { prosedürlerini iyileştirmek için öneriler sunarım. }\end{array}$ & 0,802 & & & \\
\hline $\begin{array}{l}\text { YAS4- İş birimimin hedeflerine ulaşmasına yardımcı } \\
\text { olacak yapıcı önerilerimi açıkça ortaya koyarım. }\end{array}$ & 0,758 & & & \\
\hline $\begin{array}{l}\text { YAS5- İ̧ birimimin çalışmalarını iyileştirmek için } \\
\text { öneriler sunarım. }\end{array}$ & 0,753 & & & \\
\hline $\begin{array}{l}\text { YAS1- İş birimimi etkileyebilecek konularda } \\
\text { önerilerimi ve düşüncelerimi aktif şekilde ifade } \\
\text { ederim. }\end{array}$ & 0,744 & & & \\
\hline
\end{tabular}

\subsection{Psikolojik Güvenlik Ölçeğine İlişkin Güvenilirlik ve Açıklayıcı Faktör Analizi Analizi}

Çalışanların psikolojik güvenlik algısını ölçmek için kullanılan ölçeğin güvenilirliğini tespit etmek amacıyla ölçeğin içsel tutarlılığı incelenmiştir. 5 maddelik ölçeğin güvenilirlik katsayısının 0,855 olarak bulunmuştur. Bu oran ölçeğin yüksek güvenilirlik sergilediğinin göstergesidir.

Psikolojik güvenlik ölçeğinin güvenilirlik analizi yapıldıktan sonra ölçek ifadelerinin uygun boyutlar altında toplanmasını sağlamak amacıyla varimaks rotasyonlu açıklayıcı faktör analizi uygulanmıştır. Ölçekteki 5 maddeye yapılan faktör analizinde maddeler tek faktöre yüklenmiş ve bulgular Tablo 3'de verilmiştir.

Psikolojik güvenlik ölçeğinine ilişkin beş maddenin KMO değeri 0,829 olup, küresellik testi de anlamlıdır. Yukarıdaki tabloya göre beş madde tek faktörde toplanmıştır. Beş maddeden oluşan bu faktöre "psikolojik güvenlik" adı verilmiştir. Bu faktör toplam varyansın \%63,483'ünü açıklamaktadır. 
Tablo 3. Psikolojik Güvenlik Ölçeğine İlişkin Açıklayıcı Faktör Analizi

\begin{tabular}{|c|c|c|c|c|}
\hline Faktörler & $\begin{array}{cc}\text { Faktör } & \text { Öz } \\
\text { Yükleri } & \text { Değer }\end{array}$ & $\begin{array}{l}\text { Açıklanan } \\
\text { Varyans }\end{array}$ & $\begin{array}{l}\text { Toplam } \\
\text { Varyans }\end{array}$ & $\begin{array}{l}\text { Cronbach } \\
\text { Alfa }\end{array}$ \\
\hline Psikolojik Güvenlik & 3,174 & 63,483 & 63,483 & 0,855 \\
\hline PSG- İş birimimde düşüncelerimi özgürce ifade edebilirim. & 0,852 & & & \\
\hline $\begin{array}{l}\text { PSG3- İş birimimde çalışanların gerçek duygularını açıkça } \\
\text { ortaya koyması memnuniyetle karşılanır. }\end{array}$ & 0,817 & & & \\
\hline $\begin{array}{l}\text { PSG4- İş birimimdeki diğer çalışanlardan farklı fikirlere sahip } \\
\text { olsam bile hiç kimse beni ayıplamaz. }\end{array}$ & 0,795 & & & \\
\hline $\begin{array}{l}\text { PSG5- İş birimimde gerçek düşüncelerimi ifade etmenin } \\
\text { bana zarar vereceğinden endişe duymuyorum. }\end{array}$ & 0,782 & & & \\
\hline $\begin{array}{l}\text { PSG1- İş birimimde işimle ilgili gerçek duygularımı ifade } \\
\text { edebilirim. }\end{array}$ & 0,734 & & & \\
\hline Barlett küresellik Testi: 882,481 & & & & \\
\hline
\end{tabular}

\subsection{Hipotezlerin Testi}

Değişkenler arasındaki ilişkiye yönelik gerçekleştirilen korelasyon analizi sonuçlarına Tablo 4'de yer verilmiştir. Tablo 4'e bakıldığında genel olarak örgütsel etik iklim ile çalışan sesliliği arasında doğru yönlü ve orta düzeyde bir ilişkinin var olduğu görülmektedir $(r=0,407, p=0,000)$. Araştırmanın bir diğer değişkeni olan psikolojik güvenlik ile örgütsel etik iklim arasında doğru yönlü ve oldukça güçlü bir ilişkinin var olduğu görülmektedir $(r=0,501, p=0,000)$. Ayrıca analiz sonuçları psikolojik güvenlik ile çalışan sesliliği davranışı arasında doğru yönde ve güçlü sayılabilecek bir ilişki olduğunu göstermektedir $(r=0,622, p=0,000)$.

Tablo 4. Değişkenlere İlişkin Frekans ve Korelasyon Analizi Sonuçları

\begin{tabular}{|l|c|c|c|c|c|c|c|}
\hline Değişkenler & $\overline{\mathbf{x}}$ & $\mathbf{S S}$ & $\mathbf{1}$ & $\mathbf{2}$ & $\mathbf{3}$ & $\mathbf{4}$ & $\mathbf{5}$ \\
\hline Örgütsel Etik İklim (1) & 3,22 & 0,636 & 1 & & & & \\
\hline Psikolojik güvenlik (2) & 3,24 & 0,795 & $0,501^{* *}$ & 1 & & & \\
\hline Çalışan Sesliliği (3) & 3,61 & 0,687 & $0,407^{* *}$ & $0,622^{* *}$ & 1 & & \\
\hline Yasaklayıcı Seslilik (4) & 3,65 & 0,734 & $0,318^{* *}$ & $0,458^{* *}$ & $0,899^{* *}$ & 1 & \\
\hline Teşvik Edici Seslilik (5) & 3,58 & 0,768 & $0,413^{* *}$ & $0,663^{* *}$ & $0,999^{* *}$ & $0,639^{* *}$ & 1 \\
\hline
\end{tabular}

${ }^{* *} \mathrm{p}<0,01 ;{ }^{*} \mathrm{p}<0,05$

Araştırma değişkenlerinin VIF ve tolerans indeksleri incelenmiş olup, değişkenler açısından çoklu doğrusallık probleminin olmadığını görülmüştür.

Korelasyon analizi ile değişkenler arasındaki ilişkiler ortaya konulduktan sonra regresyon analizi uygulanmıştır. Araştırma modelinde oluşturulan hipotezlerin testine ilişkin analiz bulguları ve bulgulara ilişkin yorumlar aşağıda ayrıntılı olarak yer almaktadır.

Örgütsel etik iklimin çalışan sesliliği üzerindeki etkisinde psikolojik güvenlik değişkeninin aracılık rolüne sahip olup olmadığını belirlemek amacıyla aracılık testi gerçekleştirilmiştir. Aracılık testi gerçekleştirilirken Baron ve Kenny’nin (1986) aracılık rolüne ilişkin kriterleri dikkate alınmıştır.

Örgütsel etik iklim algısına ilişkin faktörlerin ve psikolojik güvenliğin çalışan sesliliğinin boyutlarından biri olan teşvik edici seslilik üzerindeki etkilerini belirlemek amacıyla regresyon analizi yapılmıştır. Bu analizde teşvik edici seslilik bağımlı değişken, örgütsel etik iklim ve psikolojik güvenlik ise bağımsız değişken olarak ele alınmıştır. Örgütsel etik iklimin teşvik edici seslilik davranışı üzerindeki etkisinde psikolojik güvenlik değişkeninin aracılık rolüne sahip olup olmadığını belirlemek amacıyla aracılık testi gerçekleştirilmiş ve bulgular Tablo 5'de özetlenmiştir. 
Tablo 5. Örgütsel Etik İklimin Teşvik Edici Seslilik Davranışına Etkisinde Psikolojik Güvenliğin Aracı Rolüne Illişkin Regresyon Analizi

\begin{tabular}{|c|c|c|c|c|c|}
\hline \multicolumn{6}{|c|}{ 1. Adım } \\
\hline \multicolumn{6}{|c|}{ Bağımlı Değişken: Psikolojik Güvenlik } \\
\hline Değişkenler & Beta & Standart Hata & Standardize $\beta$ & $\mathrm{t}$ & $\mathrm{p}$ \\
\hline \multicolumn{6}{|l|}{ Sabit } \\
\hline Örgütsel etik iklim & 0,625 & 0,054 & 0,500 & 11,642 & 0,000 \\
\hline $\mathrm{R}^{2}$ & \multicolumn{5}{|c|}{0,250} \\
\hline Düzeltilmiş $\mathrm{R}^{2}$ & \multicolumn{5}{|c|}{0,248} \\
\hline $\mathrm{F}$ & \multicolumn{5}{|c|}{$135,527 * *$} \\
\hline \multicolumn{6}{|c|}{ 2. Adım } \\
\hline \multicolumn{6}{|c|}{ Bağımlı Değişken: Teşvik Edici Seslilik } \\
\hline Değişkenler & Beta & Standart Hata & Standardize $\beta$ & $\mathrm{t}$ & $\mathrm{p}$ \\
\hline \multicolumn{6}{|l|}{ Sabit } \\
\hline Örgütsel etik iklim & 0,499 & 0,055 & 0,413 & 9,158 & 0,000 \\
\hline $\mathrm{R}^{2}$ & \multicolumn{5}{|c|}{0,171} \\
\hline Düzeltilmiş $\mathrm{R}^{2}$ & \multicolumn{5}{|c|}{0,169} \\
\hline $\mathrm{F}$ & \multicolumn{5}{|c|}{$83,876 * *$} \\
\hline \multicolumn{6}{|c|}{ 3. Adım } \\
\hline \multicolumn{6}{|c|}{ Bağımlı Değişken: Teşvik Edici Seslilik } \\
\hline Değişkenler & Beta & Standart Hata & Standardize $\beta$ & $\mathrm{t}$ & $\mathrm{p}$ \\
\hline \multicolumn{6}{|l|}{ Sabit } \\
\hline Örgütsel etik iklim & 0,132 & 0,051 & 0,109 & 2,569 & 0,011 \\
\hline Psikolojik Güvenlik & 0,588 & 0,041 & 0,608 & 14,296 & 0,000 \\
\hline $\mathrm{R}^{2}$ & \multicolumn{5}{|c|}{0,448} \\
\hline Düzeltilmiş $\mathrm{R}^{2}$ & \multicolumn{5}{|c|}{0,446} \\
\hline $\mathrm{F}$ & \multicolumn{5}{|c|}{$165,086 * *$} \\
\hline
\end{tabular}

Örgütsel etik iklim algısının teşvik edici seslilik davranışına etkisinde psikolojik güvenliğin aracı rol üstlenip üstlenmediğini ortaya koymak için ilk adımda örgütsel etik iklim algısının psikolojik güvenlik değişkenine doğrudan etkisine bakılmıştır. Bu adımda gerçekleştirilen analizin $\mathrm{F}$ testi anlamlı sonuç vermiştir $(F=135,52 p<0,01)$ ve örgütsel etik iklim algısının psikolojik güvenlik değişkeninin toplam varyansının yaklaşık olarak \%25'ini açıkladığı görülmüştür $\left(R^{2}=0,250\right)$. Tablo 5 'te görüldüğü gibi etik iklim algısı psikolojik güvenlik değişkenini \%99 önem seviyesinde etkilemektedir $(\beta=0,500$ ve $p=0,000)$. Bu sonuçtan yola çıkarak etik bir örgüt iklimine sahip işletmelerde çalışan kişilerin kendilerini daha güvende hissettikleri söylenebilir. Bu sonuçla $\mathrm{H}_{5}$ desteklenmiştir.

Daha sonra analizin ikinci adımında örgütsel etik iklim algısının teşvik edici seslilik davranışı üzerindeki etkisini belirlemek amacıyla örgütsel etik iklim algısının teşvik edici seslilik davranışına doğrudan etkisine bakılmıştır. Bu adımda yer alan modelin $F$ testi anlamlı sonuç vermiştir $(F=83,876 p<0,01)$. Örgütsel etik iklim algısı teşvik edici seslilik davranışının toplam varyansının yaklaşık $\% 17$ 'sini açıklamaktadır $\left(R^{2}=0,171\right)$. Elde edilen bulgular örgütsel etik iklim algısının çalışanların teşvik edici seslilik davranışını \%99 önem seviyesinde etkilediğini $(\beta=0,413$ ve $p=0,000)$ ve $H_{1}^{\prime}$ 'in desteklendiğini göstermektedir.

Son olarak aracı değişken olan psikolojik güvenlik modele dahil edilerek analiz tekrarlanmıştır. Sonuçlar psikolojik güvenlik değişkeninin teşvik edici seslilik davranışını \%99 önem seviyesinde etkilediğini $(\beta=0,608$ ve $p=0,000)$ ve örgütsel etik iklim algısının teşvik edici seslilik davranışına olan etkisinin psikolojik güvenlik değişkeninin modele katılmasıyla azaldığını göstermiştir $(\beta=0,109$ ve $p=0,011)$. Mevcut durumda psikolojik güvenlik değişkeninin örgütsel etik iklim algısı ile teşvik edici seslilik davranışı arasındaki ilişkide kısmi aracı rol üstlendiği belirlenmiştir. Elde edilen tüm bulgulardan hareketle $\mathrm{H}_{3}$ ve $\mathrm{H}_{6}$ desteklenmiştir.

Örgütsel etik iklimin yasaklayıcı seslilik davranışı üzerindeki etkisinde psikolojik güvenlik değişkeninin aracılık rolüne sahip olup olmadığını belirlemek amacıyla aracılık testi gerçekleştirilmiş ve bulgular Tablo 6 'da özetlenmiştir. 
Örgütsel Etik İklim ve Çalışan Sesliliği Davranışı Arasındaki İlişki: Psikolojik Güvenliğin Aracı Rolü

Tablo 6. Örgütsel Etik İklimin Yasaklayıcı Seslilik Davranışına Etkisinde Psikolojik Güvenliğin Aracı Rolüne iliş̧kin Regresyon Analizi

\begin{tabular}{|c|c|c|c|c|c|}
\hline \multicolumn{6}{|c|}{ 1. Adım } \\
\hline \multicolumn{6}{|c|}{ Bağımlı Değişken: Psikolojik Güvenlik } \\
\hline Değişkenler & Beta & Standart Hata & Standardize $\beta$ & $\mathrm{t}$ & $p$ \\
\hline \multicolumn{6}{|l|}{ Sabit } \\
\hline Örgütsel etik iklim & 0,625 & 0,054 & 0,500 & 11,642 & 0,000 \\
\hline $\mathrm{R}^{2}$ & \multicolumn{5}{|c|}{0,250} \\
\hline Düzeltilmiş $\mathrm{R}^{2}$ & \multicolumn{5}{|c|}{0,248} \\
\hline $\mathrm{F}$ & \multicolumn{5}{|c|}{$135,527 * *$} \\
\hline \multicolumn{6}{|c|}{ 2. Adım } \\
\hline \multicolumn{6}{|c|}{ Bağımlı Değişken: Yasaklayıcı Seslilik } \\
\hline Değişkenler & Beta & Standart Hata & Standardize $\beta$ & $\mathrm{t}$ & $p$ \\
\hline \multicolumn{6}{|l|}{ Sabit } \\
\hline Örgütsel etik iklim & 0,367 & 0,054 & 0,318 & 6,762 & 0,000 \\
\hline $\mathrm{R}^{2}$ & \multicolumn{5}{|c|}{0,101} \\
\hline Düzeltilmiş $\mathrm{R}^{2}$ & \multicolumn{5}{|c|}{0,099} \\
\hline $\mathrm{F}$ & \multicolumn{5}{|c|}{$45,731 * *$} \\
\hline \multicolumn{6}{|c|}{ 3. Adım } \\
\hline \multicolumn{6}{|c|}{ Bağımlı Değişken: Yasaklayıcı Seslilik } \\
\hline Değişkenler & Beta & Standart Hata & Standardize $\beta$ & $\mathrm{t}$ & $p$ \\
\hline \multicolumn{6}{|l|}{ Sabit } \\
\hline Örgütsel etik iklim & 0,134 & 0,058 & 0,116 & 2,300 & 0,022 \\
\hline Psikolojik Güvenlik & 0,372 & 0,047 & 0,403 & 7,988 & 0,000 \\
\hline $\mathrm{R}^{2}$ & \multicolumn{5}{|c|}{0,223} \\
\hline Düzeltilmiş $\mathrm{R}^{2}$ & \multicolumn{5}{|c|}{0,219} \\
\hline $\mathrm{F}$ & \multicolumn{5}{|c|}{$58,302 * *$} \\
\hline
\end{tabular}

Örgütsel etik iklim algısının yasaklayıcı seslilik davranışına etkisinde psikolojik güvenliğin aracı rol üstlenip üstlenmediğini ortaya koymak için öncelikle ilk adımda örgütsel etik iklimin psikolojik güvenlik değişkenine doğrudan etkisine bakılmıştır. Tablo 6 'da görüldüğü gibi etik iklim algısı psikolojik güvenlik değişkenini \%99 önem seviyesinde etkilemektedir $(\beta=0,500$ ve $p=0,000)$.

Daha sonra örgütsel etik iklim algısının yasaklayıcı seslilik davranışı üzerindeki etkisini belirlemek amacıyla analizin ikinci adımında örgütsel etik iklimin yasaklayıcı sesliliğe doğrudan etkisine bakıımıştır. Bu adımda yer alan modelin $F$ testi anlamlı sonuç vermiştir $(F=45,731 p<0,01)$ ve örgütsel etik iklim algısının yasaklayıcı seslilik davranışının toplam varyansının yaklaşık $\% 10$ 'unu açıkladığı görülmüştür $\left(R^{2}=0,101\right)$. Elde edilen bulgular örgütsel etik iklim algısının çalışanların yasaklayıcı seslilik davranışını \%99 önem seviyesinde etkilediğini göstermektedir $(\beta=0,318$ ve $p=0,000)$. Bu sonuçtan hareketle $\mathrm{H}_{2}$ desteklenmiştir.

Son olarak aracı değişken olan psikolojik güvenlik modele dahil edilerek analiz tekrarlanmıştır. Bu adımda $\mathrm{F}$ testi anlamlı sonuç vermiştir $(\mathrm{F}=58,302 \mathrm{p}<0,01)$ Sonuçlar psikolojik güvenlik değiş̧keninin yasaklayıCı seslilik davranışını \%99 önem seviyesinde etkilediğini $(\beta=0,608$ ve $p=0,000)$ ve örgütsel etik iklim algısının yasaklayıcı seslilik davranışına olan etkisinin psikolojik güvenlik değişkeninin modele katılmasıyla azaldığını göstermiştir ( $\beta=0,116$ ve $p=0,022)$. Mevcut durumda psikolojik güvenlik değişkeninin örgütsel etik iklim algıSı ile yasaklayıcı seslilik davranışı arasındaki ilişkide kısmi aracı rol üstlendiği belirlenmiştir. Elde edilen tüm bulgulardan hareketle $\mathrm{H}_{4}$ ve $\mathrm{H}_{7}$ desteklenmiştir.

\section{Genel Değerlendirme ve Sonuç}

Araştırma modelinde yer alan değişkenler arasında öngörülen ilişkileri gösteren hipotezleri test edebilmek amacıyla korelasyon ve regresyon analizleri uygulanmıştır. Yapılan analiz sonucunda örgütsel etik iklim, çalışan sesliliği davranışları ve psikolojik güvenlik arasında \%99 önem seviyesinde anlamlı ilişkiler olduğu bulgusuna ulaşılmıştır.

Örgütsel etik iklim ile çalışan sesliliği arasında doğru yönlü ve orta düzeyde bir ilişkinin var olduğu belirlenmiştir. Bu sonuçtan hareketle örgütlerin etik bir iklime sahip olmaları çalışanlarının seslilik davranışları 
sergilemeleri konusunda teşvik ettiği ve çalışanların seslilik davranışı sergileyebilmeleri örgüt içerisinde oluşturulacak etik bir ortama bağlı olduğu ifade edilebilir.

Araştırmanın aracı değişkenini oluşturan psikolojik güvenliğin, örgütsel etik iklim ve çalışan sesliliği davranışı arasındaki ilişkisine bakıldığında; değişkenler arasında olumlu yönde ve orta düzeyde bir ilişkinin var olduğu görülmektedir. Örgütsel etik iklim ve çalışan sesliliği ile psikolojik güvenlik değişkeni arasında \%99 önem düzeyinde anlamlı ve doğru yönlü bir ilişki olduğu bulunmuştur. Psikolojik güvenlik kavramı çalışanların örgütlerine yönelik sahip oldukları güven duygusunu yansıtmaktadır. Bu sonuçtan yola çıkarak etik bir örgüt iklimine sahip işletmelerde çalışan kişilerin kendilerini daha güvende hissettikleri ve psikolojik güven ortamında çalışanların kendilerini daha kolay ifade edebildikleri söylenebilir.

Korelasyon analizi ile değişkenler arasında ilişki ortaya konulduktan sonra regresyon analizi uygulanmıştır. Bağımsız değişkenlerin çalışan sesliliğin alt boyutları olan "teşvik edici seslilik" ve "yasaklayıcı seslilik" ile olan ilişkilerini test etmek amacıyla yapılan regresyon analizlerinde çalışan sesliliğin boyutları ayrı ayrı bağımlı değişken olarak ele alınmıştır.

Sonuçlar örgütsel etik iklim algısının hem teşvik edici seslilik hem de yasaklayıcı seslilik davranışına olan etkisinin psikolojik güvenlik değişkeninin modele katılmasıyla azaldığını göstermiştir. Mevcut durumda psikolojik güvenlik değişkeninin örgütsel etik iklim algısı ile çalışanların seslilik davranışı arasındaki ilişkide kısmi aracı rol üstlendiği belirlenmiştir. Bu bulguya göre örgütsel etik iklim algısı hem doğrudan hem de psikolojik güvenlik aracılı̆ı̆yla çalışan sesliliği davranışını etkilemektedir. Yani örgütsel etik iklimin çalışan sesliliği üzerindeki etkisinde psikolojik güvenlik kısmi aracılık rolü üstlenmektedir. Başka bir ifadeyle, etik bir iklime sahip örgütte çalışanlar, fikir, öneri ve düşüncelerini kolaylıkla dile getirebilmektedir. Ayrıca çalışanların etik değerlere önem verilen bir örgüte sahip olmaları, psikolojik olarak kendilerini güvende hissetmelerine, düşünce ve önerileri yüzünden dışlanmamalarına yol açmaktadır.

Kamu kurumlarının vermiş olduğu sağlık hizmetine ek olarak özel firmaların artan bir oranda sektöre katılımıyla sunulan hizmetlerde bir rekabet ortamı meydana gelmiştir. Hızla artan talebe cevap vermek isteyen sağlık kuruluşlarının çalışanları yüksek tempolu iş yüküyle karşı karşıya kalmıştır. Artan iş yükü ve rekabet beraberinde sağlık çalışanlarının daha fazla etik ikilem ve problemle karşılaşmasına neden olmaktadır. Etik bir iş ikliminin oluşturulması, çalışanların karşılaştığı bu etik ikilem ve problemlere daha hızlı ve kolay cevap vermesini sağlayabilecektir. Bunun yanında sağılk alanında çalışanların fikir ve önerilerini kolayca dile getirmeleri sunulan hizmetlerin ortaya çıkaracağı hayati sonuçlar göz önünde bulundurulduğunda büyük önem arz etmektedir.

Özetlemek gerekirse etik bir iklime sahip örgütte çalışanlar, fikir, öneri ve düşüncelerini kolaylıkla dile getirebilmektedir. Ayrıca çalışanların etik değerlere önem verilen bir örgüte sahip olmaları, psikolojik olarak kendilerini güvende hissetmelerine, düşünce ve önerileri yüzünden dışlanmamalarına yol açmaktadır. Analiz sonuçları kendilerini psikolojik olarak güvende hisseden çalışanların iş birimi veya örgüt için zararlı olabilecek problemler hakkındaki bilgi veya endişelerini ilgililerle paylaştıklarını göstermektedir. Bu bağlamda psikolojik güvenlik hissine sahip çalışanların seslilik davranışları göstermeleri oldukça muhtemeldir.

$\mathrm{Bu}$ araştırmanın kısıtlarından biri araştırmanın sadece sağlık sektörünü kapsaması, maliyet ve ulaşılabilirlik nedenleriyle tek bir ilden verilerin toplanmasıdır. Ileride yapılacak araştırmalarda örneklem büyüklüğünü artırarak farklı şehirlerdeki sağlık kuruluşlarında karşılaştırılma yapılması önerilebilir.

\section{Beyan ve Açıklamalar (Disclosure Statements)}

1. Bu çalışmanın yazarları, araştırma ve yayın etiği ilkelerine uyduklarını kabul etmektedirler (The authors of this article confirm that their work complies with the principles of research and publication ethics).

2. Yazarlar tarafından herhangi bir çıkar çatışması beyan edilmemiştir (No potential conflict of interest was reported by the authors).

3. Bu çalışma, intihal tarama programı kullanılarak intihal taramasından geçirilmiştir (This article was screened for potential plagiarism using a plagiarism screening program). 


\section{Son Notlar}

1. Bu çalışma, Doç. Dr. Canan Nur KARABEY danışmanlığında Atatürk Üniversitesi Sosyal Bilimler Enstitüsünde Nisan 2019’da tamamlanan “Örgütsel etik iklim, Psikolojik Güvenlik, Güç Mesafesi Yönelimi ve Çalışan Sesliliği Davranışı Arasındaki ilişkiler" başlıklı doktora çalışmasından türetilmiştir.

\section{Kaynaklar}

Armitage, C. J., \& Conner, M. (2001). Efficacy of the theory of planned behavior: A meta-analytic review. The British Journal of Social Psychology, 40, 471-499.

Arnaud, A. (2010). Conceptualizing and measuring ethical work climate, development and validation of the ethical climate index. Business and Society, 49(2), 345-358.

Baer, M., \& Frese, M. (2003). Innovation is not enough: Climates for initiative and psychological safety, process innovationsand firm performance. Journal of Organizational Behavior, 24, 45-68.

Baron, R. M., \& Kenny, D. A. (1986), The moderator-mediator variable distinction in social psychological research conceptual, strategic and statistical considerations. Journal of Personality and Social Psychology, 51(6), 11731182.

Brown, M. E., \& Trevino, L. K. (2006). Ethical leadership: A review and future directions. Leadership Quarterly, 17(6), 595-616.

Brown, M. E., Treviño, L. K., \& Harrison, D. A. (2005). Ethical leadership: A social learning perspective for construct development and testing. Organizational Behavior and Human Decision Processes, 97, 117-134.

Chen, A. S., \& Hou, Y. H. (2015). The effects of ethical leadership, voice behavior and climates for innovation on creativity: A moderated mediation examination. Leadership Quarterly, 27(1), 1-13.

Detert, J., \& Burris, E. (2007). Leadership behavior and employee voice: Is the door really open. Academy of Management Journal, 50, 869-883.

Dutton, J. E., Ashford, S. J., Neill, R. M. O., Hayes, E., \& Wierba, E. E. (1997). Reading the wind: How middle managers assess the context for selling issues to top managers. Strategic Management Journal, 18, 407-423.

Edmondson, A. (1999). Psychological safety and learning behavior in work teams. Administrative Science Quarterly, 44, 350-383.

Frazier, M. L., Fainshmidt, S., Klinger, R. L., Pezeshkan, A., \& Vracheva, V. (2017). Psychological safety: A meta-analytic review and extension. Personnel Psychology, 70(1), 113-165.

Guerci, M., Radaelli, G., Siletti, E., Cirella, S., \& Shani, A., B. R. (2013). The impact of human resource management practices and corporate sustainability on organizational ethical climates: An employee perspective. Springer Science and Business Media Dordrecht, 327.

Hodson, R. (2001). Dignity at work. Cambridge, UK: Cambridge University Press.

Holland, P. J., Allen, B. C., \& Cooper, B. K. (2013). Reducing burnout in Australian nurses: The role of employee direct voice and managerial responsiveness. The International Journal of Human Resource Management, 24(16), 31463162.

Kahn, W. A. (1990). Psychological conditions of personal engagement and disengagement at work. Academy of Management Journal, 33(4), 692-724.

Kassing, J. W. (2002). Speaking up: Identifying employees upward dissent strategies. Management Communication Quarterly, 16, 187-209

Lee, D, Choi, Y., Youn, S., \& Chun, J. U. (2017). Ethical leadership and employee moral voice: The mediating role of moral efficacy and the moderating role of leader-follower value congruence. Journal of Business Ethics, 141, 47-57.

Liang, J., Farh, C. I., \& Farh, J. L. (2012). Psychological antecedents of promotive and prohibitive voice: A two-wave examination. Academy of Management Journal, 55, 71-73.

Matthew, J. P. (2011). Thick as thieves: The effects of ethical orientation and psychological safety on unethical team behavior. Journal of Applied Psychology, 96(2), 401-411.

Mayer, D. M., Aquino, K., Greenbaum, R. L., \& Kuenzi, M. (2012). Who displays ethical leadership, and why does it matter? An examination of antecedents and consequences of ethical leadership. Academy of Management Journal, 55(1), 151-171. 
Maynes, T., \& Podsakoff, P. (2013). Speaking more broadly: An examination of the nature, antecedents and consequences of an expanded set of employee voice behaviors. Journal of Applied Psychology, 9(1), 1-26.

Meydan, C. H., Köksal, K., \& Kara, A. U. (2016). Örgüt içinde sessizlik: örgütsel etik değerlerin etkisi ve adalet algısının aracılık rolü. Gazi Üniversitesi Iktisadi ve idari Bilimler Fakültesi Dergisi, 17(3), 142-159.

Morrison, E. W. (2011). Employee voice behavior: Integration and directions for future research. The Academy of Management Annals, 5(1), 373-412.

Morrison, E. W., \& Rothman N. B. (2009). Silence and the dynamics of power, voice and silence in organizations. (Eds.) J. Greenberg \& M. S. Edwards, Voice and silence in organizations. England: Emerald Group Publishing.

Newman, A., Kiazad, K., Miao, Q., \& Cooper, B. (2014). Examining the cognitive and affective trust-based mechanisms underlying the relationship between ethical leadership and organisational citizenship: A case of the head leading the heart. Journal of Business Ethics, 123(1), 113-123

Paşa, Ö., \& Işık A. N. (2017). Öğretmenlerin okul müdürüne güven düzeyleri ve okul müdürü tarafından sergilenen etik liderlik davranışlarının örgütsel sessizlik üzerindeki etkisi. Elektronik Sosyal Bilimler Dergisi, 16(60), 134-144.

Shafer, W. E. (2015). Ethical climate, social responsibility and earnings management. Journal of Business Ethics, 126, 4360.

Trevino, L. K., Butterfield, K. D., \& Mc Cabe D. L., (1998). The ethical context in organizations: Influences on employee attitudes and behavior. Business Ethics Quarterly, 8(3), 447-476.

Van Dyne, L., Ang, S., \& Botero, I. C. (2003). Conceptualizing employee silence and employee voice as multidimensional constructs. Journal of Management Studies, 40(6), 1359-1392.

Victor, B., \& Cullen, J. B. (1988). The organizational bases of ethical work climates. Administrative Science Quarterly, 33, 101-125.

Walumbwa, F. O., \& Schaubroeck, J. (2009). Leader personality traits and employee voice behavior: Mediating roles of ethical leadership and work group psychological safety. Journal of Applied Psychology, 94, 1275-1286. 
This Page Intentionally Left Blank 